\title{
Evaluation of Faba Bean (Vacia faba L.) Varieties for Chocolate Spot (Botrytis fabae L.) Disease Resistance at Bale Zone, Southeastern Ethiopia
}

\author{
Mekuria Wolde ${ }^{1 *}$ and Ashenafi Mitiku² \\ ${ }^{1}$ Department of Horticulture, Wolkite University, Ethiopia \\ ${ }^{2}$ Department of Plant Science, Madda Walabu University, Ethiopia
}

Submission: August 17, 2018, Published: November 16, 2018

"Corresponding author: Mekuria Wolde, epartment of Horticulture, College of Agriculture and Natural Resources, Wolkite University, Ethiopia

\begin{abstract}
A Field experiment was conducted at Agarfa and Sinana District of Bale zone with the objective to evaluate faba bean varieties for chocolate spot disease resistant. The experiment was conducted using randomized complete block design (RCBD) with three replications. The following Eight improved faba bean varieties Mosisaa, Moti, Gebelcho, Hachalu, Shallo, Tumsa, Wolki and Degaga were used in evaluating their performance. Disease severity was recorded by 1-9 disease scale with 1 no symptom and 9 heavy infection from the middle three rows of ten sample plants. Disease incidence was taken by counting the number of infected plants. AUDPC and PSI were calculated from severity. The data were analyzed by SAS computer software version 9.1.3. The result revealed that there were variations between the varieties for their chocolate spot resistant. Maximum chocolate spot severity, AUDPC and PSI data were recorded at Degaga, Hachalu and Gebelcho varieties at both experimental sites while minimum disease severity, PSI and AUDPC data were recorded from Tumsa, Shallo and Wolki varieties with a mean Severity of $(11.85 \%, 20.05 \%)$, $(11.79,21.6 \%)$ and $(13.58,19.81 \%)$ at Sinana and Agarfa Districts, respectively. The highest disease incidence was recorded from Hachalu (41.99\%, 49.79\%) and Degaga (42.38\%, 44.3\%) at Sinana and Agarfa district, respectively; while the lowest disease incidence was recorded from Tumsa (15.5\%, 20.52\%) and Wolki (19.89\%) varieties at Sinana and Agarfa Districts, respectively. The result of this study shows that Shallo, Wolki and Tumsa varieties were resistant to chocolate spot disease while Degaga, Hachalu and Gebelcho were susceptible varieties. On the other hand, Mosisaa and Moti varieties were moderately resistant. Therefore, from the result Shallo variety was performing well as compare to the other and recommended to the local farmers.
\end{abstract}

Keywords: Faba bean varieties; Disease severity; Disease incidence; Disease resistance; Chocolate spot

Abbreviations: FBLRV: Faba Bean Leaf Roll Virus: FBNYV: Faba Bean Necrotic Yellow Virus; CRBD: Completely Randomized Block Design; AUDPC: Area Under Disease Progress Curve; LSD: Least Significance Difference; DAS: Days After Sowing; PSI: Percentage Severity Index; DPC: Disease Progress Curve

\section{Introduction}

Ethiopia is the world's second largest producer of faba bean next to China, its share is only $6.96 \%$ of world production and $40.5 \%$ within Africa [1]. In Ethiopia, the average yield of faba bean under small-holder farmers is not more than 1.6 t ha-1 [2], despite the availability of high yielding varieties ( $>2 t / h a)$ [3]. The crop is among the major crops grown in Ethiopia. Demand is growing, fuelled by rapid population growth, and the gap between supply and demand continues to increase [4]. In Ethiopia, faba bean production is primarily a rain fed system.

Faba bean production is insufficient because crop yields are low because farmers grow varieties that are susceptible to diseases, insect pests, drought and high summer temperatures [4]. Globally faba bean production shows a decline trend [5]. The reasons for the decline in production are susceptibility to biotic factors [6] and abiotic stresses [7]. The major diseases affecting faba bean production in the country are chocolate spot (Botrytis fabae), Ascochyta blight (Ascochyta fabae) and faba bean rust (Uromyces viciae-fabae) which are prevalent in prolonged wet seasons [4]. Chocolate spot and rust became the important diseases worldwide. Faba bean leaf roll virus (FBLRV) and faba bean necrotic yellow virus (FBNYV) are also diseases associated with faba bean [8].

In Ethiopia, the productivity of faba bean is far below its potential due to a number of factors, the biological limitations include inherently low grain yielding potential of the indigenous cultivars and susceptibility to biotic and abiotic stresses [9]. The productivity of faba bean in Ethiopia is quite lower (15.2qt/ha) [10], as compared to about 30qt/ha in UK [11]. Faba bean varieties 
combining disease resistance with desirable traits like large seed sizes and high yield are more preferred by the farmers [12]. In Ethiopia, there are about 20 improved faba bean varieties which are adapted to different agro-ecology and have different disease reaction [13]. Most farmers in the Ethiopia cultivate local varieties [14]. Local varieties are low yielding and susceptible to both biotic and abiotic factors. Samuel et al. [15] reported that most local faba bean landraces are highly susceptible to the disease and low yielding.

Bale Zone is one of the strategic areas for the production of faba bean in Ethiopia for green and dry seed. Evaluation of high yielding and disease resistant variety is very important for farmers to sustain their production. The production of faba bean is affected by lack of improved varieties and the local varieties are susceptible to certain biotic factors like Chocolate spot and Rust and a biotic factor like Temperature, Humidity, and soil moisture is blow or above the standard it can affect the performance, growth and production of faba bean. Chocolate spot disease is among the major diseases of faba bean which threaten its productivity in Bale highlands. This raises the issue of sustainability in livelihood as a result of which the tendency for food security can be jeopardized. Hence, growing of other alternative crop species like faba bean is very important. To this end, evaluation of improved faba bean varieties for identification of chocolate spot disease resistance is among the major measures to be considered to resolve the existing problems of faba bean production and boost the productivity of the crop. Therefore, the experiment was conducted with the objective of evaluating faba bean varieties for their chocolate spot disease resistance.

\section{Materials and Methods}

\section{Description of study area}

The experiment was conducted at Bale Zone, South-eastern Ethiopia in two locations via Sinana and Agarfa district. The center represents highlands of Bale Zone with high rainfall and characterized by bimodal rainfall types. The main cropping season is locally known as Ganna extends, from half of July to September and the other cropping season locally called Bona extends from March to July. Sinana is located with the attitude range between 2361-2396masl whereas Agarfa district found with the attitude range between $2404-2501$ masl [16]. In both location the dominant soil type is clay soil and slightly acidic at pH of 6.5. Cereals (wheat and barley), legumes (faba bean and field pea) and oil crops (linseed and rapeseed) are the dominant crops cultivated in both locations.

\section{Treatments and experimental design}

Eight improved faba bean varieties were collected from different research center of Ethiopia and evaluated for their performance for chocolate spot disease under field condition. The Experiments were conducted by completely Randomized block design (CRBD) with three replications. To reduce the inter plot effect, the space between plots and blocks were adjusted at 0.5 and $1 \mathrm{~m}$, respectively. There were five rows per plot and intra and inter-row spacing was adjusted 10 and $40 \mathrm{~cm}$, respectively.
The experiment was conducted with the following varieties; Wolki (EH96049-2), Degaga (R878-3), Moti (EH95078-6), Tumsa (EH99051-3), Hachalu (EH00102-4-1), Gebelcho (EH96009-1), Shallo (EH011-22-1) [17] and Mosisaa (EH-99047-1).

At the time of planting, all plots received a basal application of Diammonium Phosphate (DAP), (18\% N, and 20\% P) at the rate of $100 \mathrm{~kg} \mathrm{ha}^{-1}$. The experimental fields and experimental units were managed as per the recommended practices for faba bean.

\section{Data collection}

The data were collected within a week interval with the inner three rows of ten sampled plant. Chocolate spot severity of faba bean was recorded using standard scale of 1-9 [18]; where, 1= No disease symptoms or very small specks; $3=$ few small discrete lesions; $5=$ some coalesced lesions with some defoliation; $7=$ large coalesced sporulating lesions, $50 \%$ defoliation and some dead plant; 9= Extensive lesions on leaves, stems and pods, severe defoliation, heavy sporulation and death of more than $80 \%$ of plants.

Diseases Severity $(\%)=\frac{\Sigma(N P C * C R)}{N I P * M S C} * 100$

Where:

NPC = Number of plants in each class rate; $\mathrm{CR}=$ Class rate; NIP $=$ No of infected plants; $\mathrm{MSC}=$ Maximum severity class rate.

Means of the severity from each plot was used in data analysis. The severity grades obtained was converted in to Percentage Severity Index (PSI) [19].

$$
\operatorname{PSI}(\%)=\frac{S n r}{N p r * M S C} * 100
$$

Where:

Snr= The sum of numerical ratings; $\mathrm{Npr}=$ Number of plant rated; $\mathrm{Msc}=$ The maximum score of the scale.

Area under disease progress curve (AUDPC) was calculated using the adapted formula by Cooke [20] as follows using the severity of each plot in fixed interval of 15 day.

$$
A U D P C=\sum_{i=1}^{n-1}\left[0.5\left(x_{i+1}+x_{i}\right)\left(t_{i+1}-t_{i}\right)\right]
$$

Where:

$x_{i}=$ The average coefficient of infection of the $i^{\text {th }}$ note; $x_{i+1}=$ The average coefficient of infection of the $i+1^{\text {th }}$ note; $t_{i+1}-t_{i}=$ The number of days between the $\mathrm{i}^{\text {th }}$ note and the $\mathrm{i}+1^{\text {th }}$ note; $\mathrm{n}=$ Number of observations.

Disease incidence was recorded within infected and noninfected crops and calculated with the following formula.

$$
\text { Disease Incidence }(\%)=\frac{\text { Number of infected plant }}{\text { Total number of plants }} * 100
$$

\section{Data analysis}

Collected data were subjected to the analysis of variance with SAS computer software version 9.1.3 [21]. Means were compared with Least Significance Difference (LSD) at 5\% probability level. 


\section{Result and Discussion}

\section{Disease severity}

Chocolate spot disease has occurred staring from 45 days after sowing (DAS) of faba bean varieties emergence at Sinana and Agarfa Districts. However, the intensities were varying in both locations. The result showed that there is a significant difference $(\mathrm{P}<0.05)$ among faba bean varieties at Sinana and Agarfa Districts. In both locations the lowest disease severity was recorded from
Tumsa, Wolki and Shallo varieties, that is, $11.85,11.79$ and $13.58 \%$ at Sinana District and 20.05, 19.81 and 21.6\%, respectively at Agarfa District. The average severity for these varieties was also low with $15.95,16.7$ and $17.04 \%$, respectively. While maximum disease severity was recorded from Degaga, Gebelcho and Hachalu varieties, that is, 22.16, 22.1 and 20.8 at Sinana District, and 35.11 28.33 and $5.31 \%$ at Agarfa District, respectively. Table 1 show the highest disease severity in Agarfa District, that is, Moti and Mosisaa varieties.

Table 1: Chocolate spot Incidence and Severity of faba beans varieties at Sinana and Agarfa District of Bale Zone.

\begin{tabular}{|c|c|c|c|c|c|c|c|}
\hline \multirow{2}{*}{ Varieties } & \multicolumn{3}{|c|}{ Incidence (\%) } & \multicolumn{3}{|c|}{ Severity $\%$} & \multirow{2}{*}{ Disease reaction } \\
\hline & Sinana & Agarfa & Average & Sinana & Agarfa & Average & \\
\hline Gebelcho & $40.32^{\mathrm{ab}}$ & $42.26^{\mathrm{ab}}$ & $41.29^{\mathrm{a}}$ & $22.1^{\mathrm{a}}$ & $28.95^{\mathrm{ab}}$ & $25.5^{\mathrm{ab}}$ & S \\
\hline Hachalu & $41.99^{a}$ & $49.79^{\mathrm{a}}$ & $45.89^{\mathrm{a}}$ & $20.8^{\mathrm{a}}$ & $35.31^{\mathrm{a}}$ & $28.05^{\mathrm{a}}$ & S \\
\hline Degaga & $42.38^{a}$ & $44.3^{\mathrm{ab}}$ & $43.34^{\mathrm{a}}$ & $22.16^{\mathrm{a}}$ & $35.11^{\mathrm{a}}$ & $28.64^{\mathrm{a}}$ & S \\
\hline Mosisa & $18.88^{\mathrm{cd}}$ & $38.95^{\mathrm{ab}}$ & $28.91^{\mathrm{bc}}$ & $15.0^{\mathrm{bc}}$ & $27.53^{\mathrm{ab}}$ & $21.27^{\mathrm{bcd}}$ & MR \\
\hline Moti & $28.32^{\mathrm{bc}}$ & $32.17^{\mathrm{bc}}$ & $30.24^{\mathrm{b}}$ & $16.2^{\mathrm{b}}$ & $28.33^{\mathrm{ab}}$ & $22.28^{\mathrm{bc}}$ & MR \\
\hline Shallo & $19.59^{\mathrm{cd}}$ & $24.76^{c}$ & $22.18^{\mathrm{bcd}}$ & $11.79^{c}$ & $21.6^{\mathrm{b}}$ & $17.04^{\text {cd }}$ & $\mathrm{R}$ \\
\hline Tumsa & $15.5^{\mathrm{d}}$ & $20.52^{c}$ & $17.7^{\mathrm{d}}$ & $11.85^{c}$ & $20.05^{\mathrm{b}}$ & $15.95^{d}$ & $\mathrm{R}$ \\
\hline Wolki & $18.10^{\text {cd }}$ & $19.89^{c}$ & $19.31^{\mathrm{cd}}$ & $13.58^{b c}$ & $19.81^{\mathrm{b}}$ & $16.7^{\mathrm{cd}}$ & $\mathrm{R}$ \\
\hline CV (\%) & 16.35 & 21.29 & 19.67 & 13.46 & 20.95 & 15.15 & \\
\hline LSD (5\%) & 12.49 & 12.56 & 10.59 & 3.89 & 9.82 & 5.75 & \\
\hline
\end{tabular}

Means with the same letter at the same column are not significantly different at $5 \%$ LSD, DAS= Days after sowing, CV= Coefficient of Variation, LSD= Least Significant difference, $S=$ Susceptible, MR= Moderately Resistant, R= Resistant.

Generally, the result revealed that chocolate spot severity was higher at Agarfa District and lower at Sinana site with a mean ranging from $19.81-35.31 \%$ and $11.79-22.16 \%$, respectively. The result of this experiment indicates that the reaction of the individual verities of faba bean varieties for chocolate spot disease was similar with the result of Tafere et al. [22] who reported that Tumsa as a resistant variety with a chocolate spot severity of $20 \%$. Similarly, Tamene et al. [23] reported that Tumsa variety was resistant to chocolate spot and Gebelcho variety was moderately resistant. The result was not inline to with the work of Tafere et al. [22] who reported that Moti, Degaga and Gebelcho have a moderate chocolate spot severity. This variation may be due to the variability of environmental conditions as the disease depends largely on environment.

\section{Disease incidence}

The result revealed that the disease incidence of chocolate spot was significantly different $(\mathrm{P}<0.05)$ among the tested varieties in both locations. The minimum chocolate spot incidence was recorded from Tumsa (15.5\%, 20.52\%), Shallo (19.52\%, 24.76\%) and Wolki $(18.80 \%, 19.89 \%)$ varieties at Sinana and Agarfa Districts, respectively. While maximum disease incidence was recorded on varieties of Degaga, Hachalu and Gebelcho varieties, with the average incidence of $42.38,41.99$ and $40.32 \%$ and 44.3 , 49.79, and $42.26 \%$ at Sinana and Agarfa Districts, respectively (Table 1).

Similar with the disease severity, the chocolate spot incidence was highest at Agarfa site which have a mean incidence ranging from 19.89-49.79\%. While disease incidence at Sinana site was lower, ranging from $15.5-42.38 \%$ (Table 1 ). This variation may be due to environmental variation between the locations, including high rainfall during the cropping season at Agarfa District. Dereje et al. [24] reported prolonged rainfall is conducive for chocolate spot development leading to complete crop loss. The high incidence at Agarfa was due to suitable environmental condition. VillegasFernandez et al. [25] reported that chocolate spot incidence is strongly influenced by climatic conditions (Table 1).

\section{AUDPC and PSI}

Significant difference was recorded among faba bean varieties $(\mathrm{P}<0.05)$ for their area under disease progress curve (AUDPC) value at both sites (Table 2). Maximum AUDPC value was recorded from Degag (2535.3\%, 1688.8\%), Gebelcho (2041.7\%, 1694.3\%) and Hachalu (2502.6, $1538.8 \%$ ) varieties at Agarfa and Sinana site, respectively. While the minimum AUDPC value was recorded from the resistant varieties including Tumsa $(1405.0 \%, 844.4 \%)$, Shallo (1680.3\%, 850.0\%-day) and Wolki (1413.6, 1013.9\%- day) at Agarfa and Sinana site respectively (Table 2).

As compared to the two locations the higher AUDPC data were recorded from Agarfa site where as the lower AUDPC was recorded at Sinana experimental site. This is may be due to environmental variation of the location. The varieties which have higher AUDPC value indicate the more susceptible one, while varieties which have lower AUDPC value are varieties which are resistant for the diseases [26]. 
In both locations, the percent severity index (PSI) shows that there is a significant difference $(\mathrm{P}<0.05)$ among the faba bean varieties evaluated for chocolate spot. Out of the tested varieties, three of them have highest PSI, Degaga $(37.78,27.90 \%)$, Hachalu (37.53, 27.65\%) and Gebelcho (32.22, 27.16\%), respectively at Agarfa and Sinana site (Table 2). However, the minimum PSI was observed from varieties which were comparatively resistant including, Tumsa, Shallo and Wolki varieties, with a corresponding PSI of $(25.31,20.99 \%),(27.65,20.12 \%)$ and $(25.19,21.11 \%)$ at Agarfa and Sinana site. Similarly, the minimum PSI was obtained comparatively from Sinana site, which indicates lower disease intensity was occurred from this site, while chocolate spot disease intensity was higher at Agarfa site during the experimentation.

Table 2: Area under disease progress curve (AUDPC) and Percent severity index (PSI) of chocolate spot disease at Agarfa and Sinana Districts.

\begin{tabular}{|c|c|c|c|c|}
\hline \multirow[t]{2}{*}{ Varieties } & \multicolumn{2}{|c|}{ PSI } & \multicolumn{2}{|c|}{ AUDPC (\%) } \\
\hline & Agarfa & Sinana & Agarfa & Sinana \\
\hline Gebelcho & $32.22^{\mathrm{ab}}$ & $27.16^{a}$ & $2041.7^{\mathrm{ab}}$ & $1694.3^{\mathrm{a}}$ \\
\hline Hachalu & $37.53^{a}$ & $27.65^{a}$ & $2502.6^{a}$ & $1538.8^{\mathrm{a}}$ \\
\hline Degaga & $37.78^{\mathrm{a}}$ & $27.90^{\mathrm{a}}$ & $2535.3^{a}$ & $1688.8^{\mathrm{a}}$ \\
\hline Mosisaa & $31.36^{\mathrm{ab}}$ & $21.85^{b c}$ & $1958.3^{\mathrm{ab}}$ & $1091.7^{\mathrm{bc}}$ \\
\hline Moti & $32.47^{\mathrm{ab}}$ & $22.96^{\mathrm{b}}$ & $1988.9^{\mathrm{ab}}$ & $1200.0^{\mathrm{b}}$ \\
\hline Shallo & $27.65^{\mathrm{b}}$ & $20.12^{c}$ & $1680.3^{b}$ & $850.0^{c}$ \\
\hline Tumsa & $25.31^{\mathrm{b}}$ & $20.99^{\mathrm{bc}}$ & $1405.0^{\mathrm{b}}$ & $844.4^{c}$ \\
\hline Wolki & $25.19^{b}$ & $21.11^{\mathrm{bc}}$ & $1413.6^{b}$ & $1013.9^{b c}$ \\
\hline CV (\%) & 14.155 & 5.89 & 23.82 & 15.62 \\
\hline LSD (5\%) & 7.64 & 2.42 & 800.41 & 335.39 \\
\hline
\end{tabular}

Means with the same letter at the same column are not significantly different at $5 \% \mathrm{LS}, \mathrm{PSI}=$ percent severity index, AUDPC $=$ area under disease progress curve, CV= Coefficient of Variation, LSD= Least Significant difference.

Generally, the chocolate spot severity, incidence, AUDPC and Hachalu, Degaga and Gebelcho varieties were susceptible to the PSI data indicated that Tumsa, Wolki and Shallo varieties were disease on both locations. On the other hand, Mosisaa and Moti resistant to chocolate spot disease at both locations. On contrary, were moderately resistant.

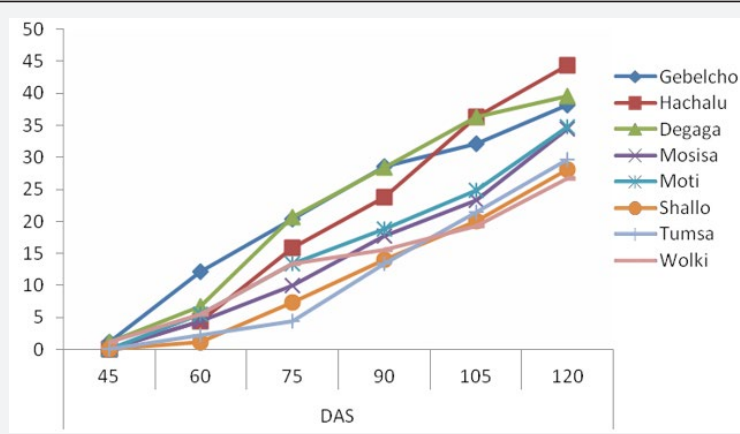

Figure 1: Disease Progress curve (DPC) for chocolate spot diseases of faba bean varieties at Sinana site.

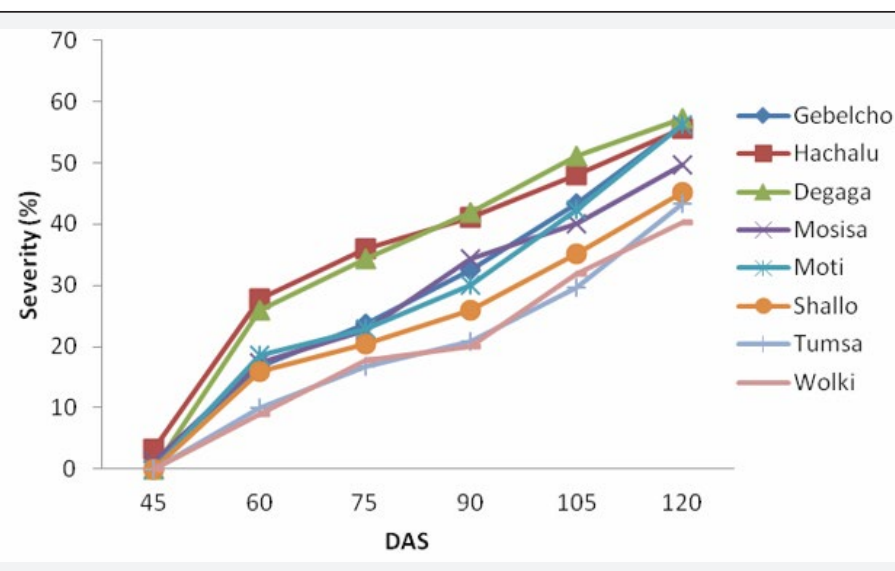

Figure 2: Disease Progress curve (DPC) for chocolate spot diseases of faba bean varieties at Agarfa site. 
The disease progress curve (DPC) of the varieties was shown on Figures $1 \& 2$. The progress curve indicates that there were a fast growth of chocolate spot disease for susceptible varieties including Degag, Hachalu and Gebelcho varieties at both sites. While the rate of disease progression was slow for resistant varieties (Tumsa, Shallo and Wolki) and the graph was more or less sloppy (Figures 1 \& 2). Similarly, the disease progression was moderate for moderately resistant varieties (Mosisaa and Moti) at both sites. The maximum disease severity was recorded from the sixth score for all varieties at both locations.

\section{Conclusion}

Chocolate spot disease is the major biotic problem that affects the productivity of faba bean varieties at Bale Zone. Identification of faba bean varieties for high yield and resistance for chocolate spot disease is impressive for Bale areas. Generally, this finding revealed that chocolate spot disease is the most important disease affecting faba bean in Ethiopia causing considerable reduction in yield. Even if chocolate spot severity and incidence were occurred at both locations the disease was more severe at Agarfa District, while minimum chocolate spot severity and incidence were recorded at Sinana District for all varieties. By this experiment resistant, moderately resistant and susceptible varieties for the disease were identified for the locations. The result revealed that from the evaluated eight faba bean varieties three of them, namely Tumsa, Wolki and Shallo varieties were resistant to chocolate spot disease. Therefore, these varieties are recommended for the farmers in the study area in their farming plan considering chocolate spot disease problem. The other three varieties were susceptible and two of them were moderately resistant to the disease in the study area.

\section{Acknowledgement}

The authors thank Madda Walabu University for their financial support.

\section{References}

1. Chopra VL, Singh RB, Varma A (1989) Crop productivity and sustainability-shaping the future. Proceedings of $2^{\text {nd }}$ international crop science congress. Oxford \& IBH publishing. New Delhi, India.

2. Central Statistical Agency (CSA) (2013) Report on area and production of major crops (private peasant holdings, meher season). Statistical bulletin 1(532): 10-14.

3. Ministry of Agriculture (MoA) (2011) Animal and plant health regulation directorate. Crop variety register. Issue No. 14. Addis Ababa, Ethiopia, pp. 71-73.

4. International Center for Agricultural Research in the Dry Areas (ICARDA) (2008) Impact of improved faba bean technologies in Africa No 2. p. 72.

5. Fouad M, Mohammed N, Aladdin H, Ahmed A, Xuxiao Z, et al. (2013) Faba Bean Genetic and Genomic Resources of Grain Legume Improvement.

6. Sillero JC, Villegas-Fernandez AM, Thomas J, Rojas-Molina MM, Emeran AA, et al. (2010) Faba bean breeding for disease resistance. Field Crop Res 115(3): 297-307.
7. Link W, Balko C, Stoddard FL (2010) Winter hardiness in faba bean: physiology and breeding. Field Crop Res 115(3): 287-296.

8. Fouad M (2011) Fababean improvement at ICARDA: Constraints and challenges 2011 Model Legume Congress Sainte Maxime, France, pp. 15-19.

9. Mussa J, Dereje G, Gemechu K (2008) Procedures of Faba Bean Improvement through Hybridization. Technical Manual No. 21, Ethiopian Institute of Agricultural Research. p. 48.

10. Central Statistical Agency (CSA) (2011) Agricultural Sample Survey Vol. I Report on Area and Production of Major Crops. The Federal Democratic Republic of Ethiopia.

11. Winch T (2006) Growing Food. A Guide to Food Production. Springer, pp. 342.

12. De Boef WS, Ogliari JB (2008) Participatory crop improvement and supporting informal seed supply. Participatory crop improvement and informal seed supply: general introduction. In: Thijssen MH, et al. (Eds.), Farmers, seeds and varieties: supporting informal seed supply in Ethiopia. Wageningen, Wageningen International. pp. 348.

13. International Food Policy Research Institute (IFPRI) (2010) Pulses Value Chain Potential in Ethiopia. Constraints and opportunities for enhancing exports. p. 44.

14. Thijssen MH, Beshir A, Bishaw Z, Van Gastel AJG, de Boef WS (2008) Seed professionals starting to approach informal seed supply through a learning and action-oriented training programme. In: Thijssen, MH, et al. (Eds.), Farmers, seeds and varieties: supporting informal seed supply in Ethiopia. Wageningen, Wageningen International, pp. 348.

15. Samuel S, Abang MM, Chemeda F, Seid A, Sakhuja PK, et al. (2008) Pathogenic and genetic diversity of Botrytis fabae Sand. isolates from faba bean fields in different agro-ecological zones of Northern Ethiopia. Archives of Phytopathology and Plant Protection 45(10): 1218-1236.

16. Ermias T, Gurmessa FC, Samuel SMW (2013) In vivo Assay for Antagonistic Potential of Fungal Isolates against Faba bean (Vicia faba L.) Chocolate Spot (Botrytis fabae Sard.). Jordan Journal of Biological Sciences 6(3): 183-189.

17. Ministry of Agriculture and Rural Development (MoARD) (2009) Animal and Plant Health Regulatory Directorate. Crop Variety Register, No. 12. Addis Ababa, Ethiopia; pp. 145.

18. Bernier HCB, Hussein MM, Mohamed HA (1984) Field manual of common faba bean diseases in the Nile Valley. International Center for Agricultural Research in the Dry Areas ICARDA. p. 40.

19. Wheeler JBJ (1969) An Introduction to Plant Diseases. CAB Direct, pp. 374.

20. Cooke BM (2006) Disease assessment and yield loss. In: Cooke BM, Gareth JD, Kaye B (Eds.), The Epidemiology of Plant Diseases ( $2^{\text {nd }} e d n$.) Published by Springer, pp. 583.

21. SAS Institute (2005s) SAS/STAT guide for personal computers, version 9.1.3 edition. SAS Institute Inc., Cary, North Carolina, USA; pp. 220.

22. Tafere M, Tadesse D, Yigzaw, D (2012) Participatory varietal selection of faba bean (Vicia faba L.) for yield and yield components in Dabat district, Ethiopia. Wudpecker J Agric Res 1(7): 270-274.

23. Tamene T, Gemechu K, Hussein M (2015) Genetic progresses from over three decades of faba bean (Vicia faba L.) breeding in Ethiopia. Aust J crop sci 9(1): 41-48.

24. Dereje G, Mengistu H, Tadesse G (1994) Influence of weather factors on infection rate of checolate spot of faba bean. Proceedings of crop protection society of Ethiopia, 26-27 April 1994. Addis Ababa, Ethiopia; pp. 33-34. 
25. Villegas-Fernandez AM, Sillero JC, Emeran AA, Winkler J, Raffiot B, et al. (2010) Identification and multi-environment validation of resistance to Botrytis fabae in Vicia faba. Field Crops Res 114(1): 84-90.
26. Fernandez-Aparicioa M, Shtaya MJY, Emeran AA, Allagui MB, Kharrat M, et al. (2011) Effects of crop mixtures on chocolate spot development on faba bean grown in Mediterranean climates. Crop Protection. 30(8): 1015-1023.

\section{Your next submission with Juniper Publishers} will reach you the below assets

- Quality Editorial service

- Swift Peer Review

- Reprints availability

- E-prints Service

- Manuscript Podcast for convenient understanding

- Global attainment for your research

- Manuscript accessibility in different formats

( Pdf, E-pub, Full Text, Audio)

- Unceasing customer service

Track the below URL for one-step submission https://juniperpublishers.com/online-submission.php 